\title{
KOMUNITAS SEBAGAI UNSUR PENTING BAGI PENGEMBANGAN KEWIRAUSAHAAN: SEBUAH PEMBELAJARAN DARI PERTANIAN HORTIKULTURA DI JAWA BARAT
}

\author{
COMMUNITY AS AN IMPORTANT ELEMENT FOR ENTREPRENEURSHIP \\ DEVELOPMENT: A LEARNING FROM HORTICULTURAL AGRICULTURE IN \\ WEST JAVA
}

\author{
Gema Wibawa Mukti*, Rani Andriani Budi Kusumo, Yosini Deliana \\ Program Studi Agribisnis Fakultas Pertanian Universitas Padjadjaran \\ *Email: gema.wibawa@unpad.ac.id \\ (Diterima 05-04-2021; Disetujui 03-06-2021)
}

\begin{abstract}
ABSTRAK
Kewirausahaan terjadi dalam suatu ruang dengan aktor yang heterogen, dimana terdapat hubungan yang kompleks diantara para aktor tersebut. Penelitian ini menitikberatkan pada pemahaman mengenai kewirausahaan dan komunitas pertanian dalam konteks pembangunan ekonomi. Penelitian kewirausahaan dirasakan belum memberikan perhatian yang cukup pada pemahaman komunitas sebagai kumpulan aktor yang berpengaruh terhadap perilaku kewirausahaan seorang pengusaha). Kami percaya bahwa kewirausahaan sangat dipengaruhi oleh keberadaan komunitas yang terdiri dari berbagai pemangku kepentingan (pemerintah, perguruan tinggi dan swasta). Pemahaman mengenai fenomena kewirausahaan dapat diperoleh dengan memahami interaksi individu dengan peluang yang ada dan lingkungan dimana wirausaha tersebut beroperasi. Hubungan antara petani sebagai pengusaha dan komunitas sebagai tempat dimana petani berusahatani menjadi penting. Modal sosial, nilai, norma dan budaya yang terdapat dalam komunitas dapat mempengaruhi kewirausahaan, baik secara positif maupun sebaliknya. Begitu pula kegiatan kewirausahaan memberikan kontribusi terhadap kehidupan masyarakat secara keseluruhan. Komunitas dan kewirausahaan adalah dua entitas yang saling mempengaruhi satu sama lain, dimana masing - masing tidak dapat berdiri sendiri. Tantangan selanjutnya bagi kami sebagai peneliti kewirausahaan adalah memperluas ruang lingkup penelitian untuk memahami kewirausahaan secara lebih komprehensif dari berbagai sudut pandang.
\end{abstract}

Kata Kunci : Komunitas,Petani, Kewirausahaan, Masyarakat Sosial

\section{ABSTRACT}

Entrepreneurship occurs in a space with heterogeneous actors, where there are complex relationships between these actors. This research focuses on understanding entrepreneurship and agricultural communities in the context of economic development. Entrepreneurship research is felt to have not paid enough attention to understanding the community as a group of actors who influence the entrepreneurial behavior of an entrepreneur). We believe that entrepreneurship is greatly influenced by the existence of a community consisting of various stakeholders (government, universities and the private sector). An understanding of the entrepreneurial phenomenon can be obtained by understanding individual interactions with existing opportunities and the environment in which the entrepreneur operates. The relationship between farmers as entrepreneurs and the community as a place where farmers cultivate is important. Social capital, values, norms and culture contained in the community can influence entrepreneurship, both positively and vice versa. Likewise, entrepreneurial activities contribute to the life of society as a whole. Community and entrepreneurship are two entities that influence each other, each of which cannot stand alone. The next challenge for us as entrepreneurship researchers is to expand the scope of research to understand entrepreneurship more comprehensively from various points of view.

Keywords: Community, Farmers, Entrepreneurship, Social Society 


\section{PENDAHULUAN}

Pembahasan mengenai wirausaha sebagai seorang individu telah banyak dibahas dalam berbagai penelitian, namun penelitian yang membahas mengenai hubungan antara pengusaha dan komunitas adalah sesuatu yang belum banyak dibahas dalam literatur kewirausahaan (Lyons et al, 2012). Kewirausahaan terjadi dalam suatu ruang dengan aktor yang heterogen, dimana terdapat hubungan yang kompleks diantara para aktor tersebut. Perilaku seorang entrepreneur dapat memberikan dampak yang positif, seperti membuka lapangan pekerjaan dan meningkatkan perekonomian masyarakat yang berada di sekitar para entrepreneur tersebut. Namun sebaliknya perilaku mereka juga dapat memberikan dampak yang kontraproduktif, seperti misalnya persaingan tidak sehat atau eksploitasi alam yang berlebihan sehingga menimbulkan kerusakan lingkungan.

Kebijakan yang terkait dengan pengembangan kewirausahaan juga tentunya memberikan dampak yang beragam bagi suatu komunitas. Penyediaan ruang tumbuh pengusaha, penyediaan sarana dan prasarana serta penguatan akses ke lembaga keuangan secara tidak langsung telah membantu pengembangan suatu komunitas. Namun beberapa kebijakan juga dapat memberikan kesulitan kepada suatu komunitas, seperti misalnya impor produk pertanian yang menyebabkan harga di petani menjadi rendah, sehingga petani merugi dan kurang bergairah untuk kembali mengusahakan produk pertanian. Hubungan antara pelaku wirausaha dan komunitas dapat saling menguntungkan namun juga sebaliknya dapat saling merugikan.

Berdasarkan fenomena tersebut, diperlukan suatu pemahaman mengenai peran dari kedua aktor tersebut (pelaku wirausaha dan komunitas) dalam pengembangan kewirausahaan dalam kehidupan masyarakat. Tantangan yang dihadapi oleh pelaku wirausaha dan komunitas adalah membangun interaksi yang produktif. Keberadaan pelaku wirausaha menjadi penting bagi sebuah komunitas, karena dapat membuka lapangan pekerjaan, menggerakkan perekonomian dan membantu komunitas untuk mendukung upaya kewirauusahaan (Fairlie, 2013). Penelitian ini menitikberatkan pada pemahaman mengenai kewirausahaan dan komunitas pertanian dalam konteks pembangunan ekonomi. Kami melihat kondisi eksisting bidang pertanian, interaksi diantara 
komunitas dan para pelaku wirausaha pertanian serta faktor penentu yang memberikan kontribusi dalam implementasi nya. Kami juga mencoba untuk melihat peluang penelitian di masa yang akan datang terkait dengan bidang ini.

\section{KERANGKA TEORITIS}

Penelitian ini akan dimulai dengan mendefinisikan beberapa istilah penting sebelum kemudian melihat hubungan antara pelaku wirausaha dan masyarakat. Pada bagian ini akan dijelaskan apa yang dimaksud dengan komunitas (masyarakat), kewirausahaan dan bagaimana pengembangan komunitas yang dimaksud dalam penelitian ini.

\section{Komunitas}

Komunitas merupakan frasa / kata yang sering kita dengar dalam kehidupan sehari-hari. Konotasi frasa "komunitas" ini berbeda-beda pada setiap individu, tergantung bagaimana seseorang mempersepsikan komunitas tersebut. Komunitas seringkali di-persepsikan sebagai fungsi sosial ekonomi, topografi, kondisi iklim dan juga sebuah kesatuan nilai dan norma yang berlaku pada suatu tempat. Komunitas terdiri dari berbagai unsur, mulai dari individu, keluarga, kelompok tani, gabungan kelompok tani dan interaksi masyarakat lainnya dalam suatu wadah tertentu. Komunitas terdiri dari para aktor yang saling terhubung karena adanya indentitas, bahasa, nilai dan norma, peranan, moral dan sosial yang relatif sama antara satu dengan yang lainnya (Sampson, 2011; Tonnies \& Loomis, 2002; Wellman, 1999).

Interaksi antar aktor dalam sebuah komunitas melibatkan perasaan (emosional) dan fisik. Komitmen seorang aktor muncul setelah terdapat pengakuan atau penerimaan dari aktor lain dari suatu komunitas. Komunitas muncul karena terdapat aktor/individu yang berjuang bersama - sama untuk mewujudkan masa depan yang lebih baik bagi mereka (Crow \& Allan, 2014). Komunitas dibangun karena terdapat perbedaan dan persamaan diantara para aktor, sehingga muncul interaksi diantara para individu untuk berjuang bersama dalam mencari sebuah peluang bagi kehidupan mereka. Pengembangan diri tidak dapat dilepaskan dari peranan individu lain dalam lingkungan kita. Manusia pada masa "digital" ini dirasakan semakin individualistis, namun kita tetap membutuhkan orang lain untuk menemukan diri kita sendiri (Lyons et al, 2012). Melalui kehidupan dalam suatu komunitas, kita menjalin interaksi dengan 
individu lain, sehingga kita dapat memahami hidup kita sendiri (Kemmis, 2001).

Masyarakat tani di Indonesia adalah masyarakat yang guyub, dimana interaksi diantara para pelaku pertanian sangat kuat dan saling memperkuat satu sama lain. Sistem kapitalisme sedikit demi sedikit telah merubah "guyub" tadi menjadi interaksi yang bersifat “ transaksional". Hubungan antar petani semakin dipengaruhi oleh alasan ekonomi, hubungan timbal balik yang didasarkan atas aktivitas jual beli, bukan lagi didasarkan pada hubungan kekeluargaan. Hal ini juga telah mendorong petani untuk menjalakan bisnis nya secara individu, menganggap petani lainnya sebagai pesaing, bukan lagi teman yang dapat saling mendorong pada sebuah kemajuan bersama. Individualisme menurut ilmuwan sosial adalah upaya seseorang untuk melindungi diri mereka. Namun cara ini justru tidak melindungi diri mereka, sebaliknya semakin mempersulit mereka untuk bekerja dalam suatu lingkungan yang kompleks dan dinamis. Kondisi ini mendorong setiap pelaku usaha pertanian untuk saling berkolaborasi, saling melengkapi satu sama lain, bekerjasama untuk dapat memenuhi kebutuhan konsumen akan produk pertanian.

Komunitas atau masyarakat pertanian menghadapi banyak tantangan yang sulit, diantaranya adalah : (1) Sifat individualisme yang masih diterapkan dalam aktivitas ekonomi, (2) Masih terdapat "Isme" semu yang cenderung memisahkan satu aktor masyarakat dengan aktor lainnya, (3) Masih terdapat perbedaan hierarkis dalam kehidupan masyarakat dan ketergantungan masyarakat terhadap sosial birokrasi yang masih tinggi, (4) Hubungan "transaksional" lebih dominan daripada hubungan "sosial", (5) Mudah terbawa gaya hidup yang di-“arus utama" kan oleh media sosial/massa, (6) Profesional sebagai seorang karyawan masih dianggap lebih prestisius dibandingkan dengan profesi sebagai wirausaha. Tantangan-tantangan ini telah menimbulkan kekhawatiran bahwa perubahan modal sosial akan melemahkan komunitas-masyarakat (Aldrich \& Meyer, 2015; Kawachi, 1999).

\section{Kewirausahaan}

Kewirausahaan adalah konsep yang meliputi banyak dimensi yang secara relatif sulit untuk didefinisikan secara pasti (Carree \& Thurik, 2005). Pemikiran 
mengenai kewirausahaan telah berkembang sedemikian rupa, menawarkan sebuah konseptualisasi baru dari berbagai perilaku ekonomi yang memiliki sifat kewirausahaan. Dalam fungsi ekonomi, kewirausahaan berperan sebagai agen perubah, penggerak perekonomian dan juga sebagai pembawa inovasi dalam suatu wilayah (Karlsson et $a l, 2004)$. Dalam konsep ekonomi pasar modern, wirausaha adalah agen ekonomi yang mengasumsikan perilaku inovatif dan aktif, yang bersedia untuk menerima risiko keuangan dalam pengembangan usaha baru. Secara singkat, kewirausahaan identik dengan pencapaian individu dalam bidang bisnis. Hal ini kemudian berkembang ketika bisnis telah berkembang, dimana perilaku kewirausahaan orang-orang yang terlibat dalam organisasi atau perusahaan menjadi vital dalam keberhasilan perusahaan tersebut. Kewirausahaan tidak hanya fokus pada desain bisnis, namun juga pada pengembangan setiap individu dalam organisasi sehingga aktivitas bisnis terus dapat berlangsung dan membawa perkembangan positif terhadap aktivitas bisnis itu sendiri (Panda, 2000).

Kewirausahaan dalam kegiatan bisnis tampaknya telah menjadi suatu keniscayaan, di tengah segala perubahan yang serba cepat. Kewirausahaan menjadi faktor penting bagi manusia karena tingkat kebutuhan yang senantiasa meningkat dan perubahan lingkungan yang terus terjadi (Arisena, 2016). Perubahan tersebut berlangsung di semua sendi kehidupan manusia, dimana mereka yang mampu bertahan adalah mereka yang dapat beradaptasi dengan perubahan tersebut. Wirausaha adalah orang-orang yang memiliki orientasi terhadap proses atau usaha (tindakan), memiliki motivasi tinggi untuk mewujudkan mimpi atau tujuannya serta berani mengambil risiko dalam menjalani pilihannya tersebut (Meredith Geoffrey, 2000).

$$
\text { Menurut Drucker }
$$
kewirausahaan adalah suatu kemampuan untuk menciptakan sesuatu yang baru dan berbeda (ability to create the new and different thing). Secara epistemology, kewirausahaan merupakan nilai yang diperlukan untuk memulai suatu usaha (start-up phase) atau suatu proses dalam mengerjakan sesuatu yang baru (creative) dan sesuatu yang berbeda (innovative). Menurut Zimmerer (1996), Kewirausahaan adalah penerapan kreativitas dan inovasi untuk memecahkan persoalan dan menghadapi peluang yang dihadapi setiap hari. 
Kewirausahaan merupakan gabungan dari kreativitas, inovasi dan keberanian dalam menghadapi risiko yang dilakukan dengan cara kerja keras untuk membentuk dan memelihara usaha baru. Secara ringkas kewirausahaan dapat didefinisikan sebagai suatu kemampuan kreatif dan inovatif yang dijadikan kiat, dasar, sumberdaya, proses dan perjuangan untuk menciptakan nilai tambah produk dan jasa yang dilakukan dengan keberanian untuk menghadapi risiko.

\section{HASIL DAN PEMBAHASAN}

\section{Hubungan Antara Komunitas dan Kewirausahaan}

Pada bagian ini akan dibahas mengenai keterkaitan antara kewirausahaan dan komunitas (masyarakat), bagaimana keduanya memiliki relevansi satu sama lain. Bidang ilmu kewirausahaan pada satu sisi fokus pada pemahaman pelaku wirausaha sebagai seorang individu, sedangkan pada sisi lainnya fokus pada pengaruh eksternal yang mempengaruhi fenomena kewirausahaan (Shane, 2003). Pembahasan kewirausahaan secara terpisah menyulitkan para peneliti kewirausahaan untuk menjelaskan secara komprehensif fenomena kewirausahaan yang dipengaruhi oleh lingkungan sekitar. Komunitas/masyarakat merupakan "ekosistem" bagi petani untuk menjalankan aktivitas bisnis, yang menyediakan sumberdaya alam, sumberdaya manusia dan dukungan sosial yang menguntungkan. Komunitas menyediakan peluang yang dapat dimanfaatkan oleh seorang pelaku wirausaha pertanian (Anderson \& Gaddefors, 2016).

Pengusaha adalah individu yang memiliki keterampilan untuk mengejar peluang (Lichtenstein \& Lyons, 2010). Dalam hal ini komunitas berperan dalam pengembangan peluang secara bersama sama untuk mendorong pertumbuhan aktivitas usaha. Budaya dan norma (modal sosial) menjadi aspek penting dalam pengembangan kewirausahaan. Terutama dalam bidang pertanian, pengembangan ini melalui proses yang inklusif dan partisipatif (Nicotra et al, 2018; Boder, 2006). Modal sosial digunakan untuk mendorong terjadinya pertumbuhan usaha dan juga perubahan sosial (Edelman et al, 2010). Modal sosial bagi seorang calon wirausaha atau wirausaha baru misalnya seperti jejaring bisnis, norma, nilai, aturan main yang dapat mengakomodir aktivitas bisnis yang menciptakan nilai dan saling menguntungkan satu sama lain (Nicotra 
et al, 2018). Jaringan menjadi kata kunci yang penting dalam konsep modal sosial. Melalui interaksi antar aktor, seorang wirausaha dapat memperoleh pengetahuan, keterampilan, belajar untuk memperoleh sumberdaya secara efisien dan mampu mendapatkan pelanggan yang potensial.

Membangun dan memperkuat jejaring wirausaha sangat penting untuk pengembangan kewirausahaan. Memperkuat interaksi diantara para aktor dalam sebuah komunitas dapat memperluas akses seorang wirausaha terhadap suatu peluang. Kebutuhan komunitas secara umum menjadi lebih penting dibandingkan dengan kepentingan wirausaha secara individu, sehingga diperlukan interaksi dan komunikasi dari berbagai bidang dan pelaku usaha. Seorang wirausaha perlu menyadari bahwa perlu ada keselarasan antara pertumbuhan usaha nya dan pertumbuhan lingkungan sekitarnya, sehingga tidak menimbulkan "konflik" dengan kepentingan lokal.

Interaksi diantara para aktor dalam suatu komunitas dan modal sosial dapat mengembangkan perilaku wirausaha para individu yang terdapat di dalam nya, meskipun dalam implementasi nya masih relative sulit untuk mendapatkan manfaat yang optimal dari keberadaan modal sosial dalam komunitas (Bridger \& Alter, 2006). Meskipun demikian, modal sosial telah memberikan banyak kemajuan dalam pengembangan kewirausahaan di suatu komunitas. Komunitas telah memberikan kontribusi dalam upaya sistemik dalam pengembangan, penguatan dan fasilitasi bagi para wirausaha (Lichtenstein \& Lyons, 2010; Nicotra et al, 2018).

\section{Komunitas dan Kewirausahaan}

Kewirausahaan dalam sebuah komunitas adalah "lokomotif" bagi perubahan sosial (Selsky \& Smith, 1994). Perubahan sosial berbasis komunitas adalah sesuatu yang dinamis dan kompleks, memiliki beragam kepentingan dari para aktor yang terlibat di dalam nya. Seorang wirausaha dalam suatu komunitas umumnya memiliki (1) Mampu berperan dalam berbagai kegiatan (multi tasking), (2) memiliki komitmen yang kuat dan mampu memobilisasi sumberdaya, (3) Selalu belajar dan beradaptasi terhadap kondisi sosial yang dinamis (Selsky \& Smith, 1994).

Kewirausahaan berbasis komunitas melibatkan berbagai kelembagaan dengan hubungan yang kompleks dan dinamis. 
Kondisi ini mengharuskan setiap organisasi/lembaga harus terus beradaptasi dan berkomunikasi satu sama lain untuk menghadapi berbagai perubahan yang selalu terjadi. Ada kalanya dibutuhkan organisasi yang bertindak sebagai agen perubahan dalam proses adaptasi tersebut. Dalam pengembangan komunitas melibatkan para aktor berbeda yang mengembangkan tujuan bersama dan meraih keberhasilan dalam tujuan mereka tersebut (Fortunato \& Alter, 2015).

Pengembangan komunitas dalam wirausaha pertanian melibatkan struktur, norma dan peran kelembagaan. Peran kepemimpinan dalam pengembangan wirausaha dalam komunitas menjadi penting, karena hal ini dapat membantu mereka untuk mengontrol lingkungan, termasuk kolaborasi antar aktor dalam komunitas tersebut. Kewirausahaan dan komunitas saling memperkuat satu sama lain dalam sebuah siklus pertumbuhan. Kami mengusulkan agar penelitian di masa depan tidak hanya berfokus pada pelaku wirausaha sebagai individu, namun pada pelaku wirausaha sebagai bagian tidak terpisahkan dari suatu komunitas. Wirausaha komunitas memiliki kemampuan untuk mengakomodir keragaman kepentingan dan menumbuhkan pemahaman bersama diantara berbagai pemangku kepentingan yang ada. Mereka selalu berusaha untuk membangun "keunggulan kolaboratif", memperjelas kontribusi dari setiap aktor sesuai dengan sumberdaya yang dimiliki oleh masing - masing pihak, (2) Menghormati kepentingan setiap aktor yang terlibat dan dapat mengindentifikasi sumberdaya yang diperlukan dari masing-masing pihak untuk mendorong terjadinya kolaborasi, (3) Memperkuat komitmen bersama untuk mencapai tujuan bersama (Anderson \& Gaddefors, 2016).

Petani yang memiliki karakteristik sebagai wirausaha selalu berusaha untuk memberikan dampak positif bagi lingkungan nya, sehingga dapat membuka peluang-peluang baru dan produktif bagi diri dan petani lain di sekitar nya. Agar hubungan antara pelaku wirausaha (petani) dan masyarakat dapat memberikan manfaat bagi kedua belah pihak, maka diperlukan beberapa pemahaman mengenai (1) Kontribusi pengusaha terhadap komunitas nya, (2) pendekatan yang komprehensif, pemahaman bahwa pengembangan usaha pada prinsipnya adalah pengembangan manusia, tidak semata pengembangan aset/finansial dari komunitas tersebut 
saja, (4) komunitas merupakan sebuah "organisasi pembelajaran" dan pengembangan modal sosial.

Aktivitas kewirausahaan memiliki korelasi yang positif dengan pertumbuhan ekonomi (Aparicio et al, 2016). Inisiatif yang muncul dari seorang wirausaha merupakan aspek penting dalam mengenali peluang dan inovasi. Kewirausahaan dapat memberikan manfaat bagi masyarakat, dan sebaliknya masyarakat juga dapat berkontribusi dalam pengembangan kewirausahaan. Masyarakat berperan sebagai penyedia sumberdaya sekaligus sebagai pasar bagi produk kewirausahaan. Meskipun jumlah petani, terutama petani muda/milenial, bervariasi di setiap wilayah, namun kontribusi mereka terhadap masyarakat sangat tergantung kepada aktivitas produktif yang mereka lakukan. Aktivitas produktif ini menciptakan hubungan saling menguntungkan antara petani dengan masyarakat. Bentuk hubungan mutualisme ini misalnya seperti semakin terbuka nya kesempatan kerja bagi masyarakat, semakin besar peluang bagi generasi muda untuk menjadi wirausaha dan peningkatan pendapatan daerah yang berasal dari kinerja para wirausaha di lingkungan tersebut.
Masyarakat atau komunitas adalah wadah pembelajaran yang sangat lengkap dan kompleks bagi seorang wirausaha atau calon wirausaha. Komunitas membantu mereka untuk meningkatkan kemampuan dalam menangkap peluang dan kepekaan terhadap lingkungan. Aspek etika bisnis, kewirausahaan sosial dan tanggung jawab sosial perusahaan mungkin diajarkan di sekolah/perguruan tinggi, namun tentunya diperlukan pemahaman lebih mendalam mengenai hubungan mereka dengan komunitas dimana mereka menjalankan bisnis nya. Seorang calon petani perlu mendapatkan informasi mengenai kewirausahaan dalam konteks pengembangan masyarakat, untuk memahami bahwa terdapat keterkaitan antara masyarakat dan kewirausahaan. Sebuah komunitas dapat mendukung pengembangan kewirausahaan, namun tentunya dapat berlaku pula sebaliknya, dimana komunitas dapat juga merusak hal tersebut. Secara lebih detail bagian ini akan dibahas pada subbab berikutnya.

\section{Interaksi antara Kewirausahaan dan Masyarakat}

Budaya yang berlaku dalam komunitas pertanian merupakan aspek penting dalam kewirausahaan. Hal ini diperkuat oleh dukungan dari 
kelembagaan pertanian yang secara efektif fokus membantu petani skala kecil untuk berkembang, membuka akses terhadap peluang yang ada melalui jejaring bisnis yang heterogen. Komunitas tentu memiliki keterlibatan dalam aktivitas kewirausahaan, apakah itu memiliki dampak atau tidak berdampak apapun. Ketika pemerintah sebagai pemangku kepentingan dalam sektor pertanian mengeluarkan kebijakan untuk impor beras, hal ini dapat "merusak" harga beras di tingkat petani, dan pada akhirnya memberikan dampak negatif bagi usahatani yang mereka jalankan. Pelibatan petani dalam penyusunan sebuah kebijakan menjadi sesuatu yang penting, agar pengembangan ekonomi masyarakat yang diusung oleh para pemangku kepentingan dapat berjalan secara efektif dan tidak merugikan petani sebagai ujung tombak pertanian Indonesia.

Petani sebagai pelaku bisnis akan berusaha untuk memenuhi kebutuhan produksi, berivestasi untuk kelanjutan usahanya, menabung bagi masa depan nya dan efisien dalam bisnis nya. Di sisi lain, pemerintah berusaha untuk menjaga stabilitas dan ekuitas. Kedua aspek ini secara tidak langsung membantu petani dapat menjalankan bisnis nya dengan aman dan tenang. Seringkali hal ini kurang dipahami oleh pelaku wirausaha karena kedua aspek tersebut tidak dikerjakan oleh petani dalam aktivitas sehari - hari nya. Penulis berpendapat bahwa mungkin saja petani dapat memiliki efek negatif bagi perekonomian, dimana mereka menjadi beban bagi negara. Petani yang tidak inovatif dan produktif tentu akan menjadi beban bagi lingkungan nya, namun sebaliknya, petani juga dapat mendorong pertumbuhan ekonomi secara signifikan. Kondisi ini membawa kita pada pertanyaan, petani wirausaha seperti apa yang sesuai bagi komunitas pertanian? Apakah petani yang berbasis internet (IOT) lebih baik dibandingkan dengan yang lain?

Pada masa pandemi covid 19, dimana setiap orang memiliki keterbatasan untuk bergerak, muncul anggapan bahwa petani yang menggunakan teknologi tinggi lebih adaptif terhadap perubahan dibandingkan dengan petani tradisional, apakah memang demikian adanya? Perspektif ini tentunya akan sangat tergantung kepada kebutuhan komunitas yang merasakan nya langsung. Apabila komunitas memang membutuhkan pengembangan pertanian yang berteknologi tinggi, 
tentunya hal ini yang harus menjadi fokus pengembangan kewirausahaan pada komunitas tersebut. Pada satu sisi, kita juga harus melihat perspektif dari sisi kebutuhan petani itu sendiri. Model bisnis yang sesuai dengan petani tentunya model yang dapat meningkatkan pendapatan dan juga kesejahteraan petani. Model bisnis petani yang masuk akal adalah model yang dapat memenuhi kebutuhan pasar lokal yang dapat dijangkau oleh petani. Komunitas dalam hal ini membantu petani untuk dapat menjalankan model bisnis nya tersebut, sehingga dapat tercipta transformasi ekonomi komunitas secara efektif (Lichtenstein \& Lyons, 2001, 2010).

Petani sebagai seorang individu harus memiliki kapasitas dan motivasi untuk memanfaatkan setiap peluang yang disediakan oleh komunitas. Ketika petani dapat menangkap peluang tersebut, maka dia dapat memberikan kontribusi dalam pengembangan masyarakat baik secara langsung ataupun tidak langsung. Petani harus percaya bahwa usaha mereka memang dapat diterima oleh komunitas, sehingga petani memiliki kepercayaan diri dalam menjalankan usahanya. Kolaborasi petani dengan kelembagaan lainnya dilakukan untuk saling memperkuat satu sama lain, bukan sebaliknya. Norma, nilai, aturan dan sejarah suatu wilayah tentu mempengaruhi kemampuan seorang petani untuk berkembang. Seseorang memilih untuk menjadi petani mungkin tidak hanya untuk mengejar keuntungan atau efisiensi, namun telah menjadi gaya hidup yang diajarkan oleh komunitas di sekitarnya, dan untuk memenuhi kebutuhan lokal.

Peneliti menilai bahwa sulit untuk melihat secara pasti apa pilihan strategis petani, sikapnya terhadap risiko atau sumber inspirasi nya, namun kita dapat menganalisis apa yang mendorong mereka untuk berwirausaha dalam bidang pertanian. Budaya yang berlaku dalam sebuah komunitas/masyarakat sosial akan mempengaruhi seorang pengusaha (petani) dalam memandang lingkungan nya, yang pada akhirnya akan mempengaruhi pilihan strategis yang dibuat oleh pengusaha dan tingkat keberhasilannya (Chrisman et al, 2002; Lyons et al, 2012). Analisis yang dilakukan terhadap persepsi petani mengenai usahatani dan keberhasilan usaha, petani diminta untuk membuat prioritas terhadap apa yang mereka hadapi saat ini. Petani diminta untuk melihat dan menilai beberapa prioritas dalam aktivitas usahanya, seperti (1) 
Ketersediaan sumberdaya manusia terampil dan produktif; Sektor pertanian saat ini terkendala oleh keterbatasan tenaga kerja yang terampil dan produktif. Sektor industri non pertanian masih dianggap lebih menjanjikan dibandingkan dengan pertanian, sehingga sumberdaya manusia berkualitas banyak terserap ke sektor non pertanian. Hal ini menyebabkan petani masih kesulitan mencari SDM yang berkualitas bagi pengembangan usahanya. (2) Globalisasi, perdagangan bebas dan digitalisasi pertanian; petani saat ini dihadapkan pada perilaku pasar yang berubah secara drastis, salah satu nya disebabkan oleh pandemi covid 19. Perubahan pasar telah mendorong petani untuk beradaptasi dan memperbaharui model bisnis nya, (3) Peraturan pemerintah, (4) Teknologi Informasi, perkembangan teknologi informasi saat ini menuntut petani untuk senantiasa belajar, memperkuat kemampuan diri dalam penguasaan teknologi informasi, sehingga usahanya dapat bertahan dan berkembang, (5) Akses terhadap lembaga keuangan dan (6) Pemasaran produk pertanian.

Berdasarkan temuan di lapangan, peneliti menemukan bahwa petani di Jawa Barat memberikan perhatian lebih terhadap perubahan perilaku pasar yang signifikan pada masa pandemi covid 19 ini. Beberapa petani juga menyatakan kekhawatirannya pada semakin berkurangnya tenaga kerja pertanian yang terampil dan produktif. Mereka juga saat ini mulai memberikan perhatian pada digitalisasi pertanian, karena pasar online yang semakin berkembang sehingga mendorong petani untuk mulai beralih pada digitalisasi pertanian. Petani telah menyadari perubahan yang terjadi di komunitas nya, namun saat ini sebagian besar petani belum dapat mengantisipasi perubahan tersebut. Petani dalam penelitian ini umumnya berasal dari keluarga petani, sehingga keputusan mereka untuk bertani banyak dipengaruhi oleh keluarga. Bisnis keluarga cenderung memiliki pandangan yang lebih sempit dan belum menyadari pentingnya perubahan di lingkungan sekitar usaha mereka. Keluarga petani cenderung memilih untuk memasuki pasar dengan tingkat persaingan yang lebih rendah dan relatif mudah untuk dimasuki (misal : menjual hasil panen kepada pedagang pengumpul atau menjual ke pasar tradisional). Cara pemasaran ini memudahkan petani untuk "segera" menjual hasil panen nya dan mendapatkan uang tunai sebagai modal 
untuk kegiatan produksi selanjutnya dan memenuhi kebutuhan hidup mereka sehari-hari.

\section{Keluarga, Komunitas dan Petani}

Keluarga merupakan elemen penting dalam masyarakat/komunitas dan memiliki peranan penting dalam pengembangan kewirausahaan (Danes et al, 2008; Dou et al, 2020). Semangat berwirausaha seorang individu berasal dari dukungan internal keluarga, sebelum kemudian mendapatkan dukungan dari berbagai pihak di luar keluarga. Dukungan keluarga berupa sumberdaya keuangan (modal), pendidikan dan sumberdaya manusia merupakan faktor penentu utama seorang individu memiliki motivasi untuk berwirausaha (petani) (Carr \& Roulin, 2016). Keluarga memberikan dukungan penting dalam setiap tahapan bisnis yang dilakukan oleh petani (Randerson et al, 2015). Dukungan keluarga dalam pengembangan kewirausahaan meliputi penyediaan sumberdaya, jaringan sosial, modal sosial dan motivasi bagi seorang wirausaha. Hal ini memberikan pengaruh besar dalam membentuk kemampuan wirausaha seorang individu.

Keluarga memiliki peranan penting sebagai saluran nilai dan norma di masyarakat kepada pelaku wirausaha secara individu. Pertanian pada umumnya adalah bisnis keluarga, yaitu usaha yang dimiliki oleh keluarga, dikelola oleh kepala keluarga dan dibantu oleh anggota keluarga lainnya, memerlukan keterlibatan anggota keluarga dalam operasional usahatani. Berdasarkan pengamatan yang dilakukan di lapangan, petani, keluarga dan komunitas tidak dapat dipisahkan. Ketiga "aktor" tersebut memiliki peranan yang penting dalam membangun kewirausahaan, menjadi "infrastruktur" penting dalam pengembangan kewirausahaan pertanian. Berdasarkan penelusuran literatur, penelitian mengenai bisnis keluarga petani dirasakan masih kurang lengkap, sehingga peneliti menganggap bahwa penting untuk memperluas fokus penelitian yang dapat menggambarkan hubungan antara kewirausahaan dan keluarga dalam sebuah komunitas.

\section{KESIMPULAN}

Penelitian kewirausahaan dirasakan belum memberikan perhatian yang cukup pada pemahaman komunitas sebagai kumpulan aktor yang berpengaruh terhadap perilaku kewirausahaan seorang pengusaha (Martinez et al, 2011). Kami percaya bahwa kewirausahaan sangat 
dipengaruhi oleh keberadaan komunitas yang terdiri dari berbagai pemangku kepentingan (pemerintah, perguruan tinggi dan swasta). Literatur yang menjelaskan tentang hubungan antara kewirausahaan dan komunitas dirasakan masih terbatas. Kewirausahaan tidak dapat dipahami secara komprehensif hanya dengan mempelajari pelaku wirausaha sebagai seorang individu. Pemahaman mengenai fenomena kewirausahaan dapat diperoleh dengan memahami interaksi individu dengan peluang yang ada dan lingkungan dimana wirausaha tersebut beroperasi. Hubungan antara petani sebagai pengusaha dan komunitas sebagai tempat dimana petani berusahatani menjadi penting.

Modal sosial, nilai, norma dan budaya yang terdapat dalam komunitas dapat mempengaruhi kewirausahaan, baik secara positif maupun sebaliknya. Begitu pula kegiatan kewirausahaan memberikan kontribusi terhadap kehidupan masyarakat secara keseluruhan. Komunitas dan kewirausahaan adalah dua entitas yang saling mempengaruhi satu sama lain, dimana masing-masing tidak dapat berdiri sendiri. Modal sosial yang disediakan oleh komunitas dapat memfasilitasi terciptanya peluang bisnis, sumberdaya manusia, pengembangan kapasitas kewirausahaan dan pertumbuhan ekonomi. Hubungan antara kewirausahaan dan komunitas dalam bidang pertanian adalah hubungan yang kompleks, berupa kemitraan yang harus memberikan keuntungan bagi semua pihak. Tentunya untuk mencapai hal ini, kebutuhan dan peranan dari setiap aktor yang terlibat harus dielaborasi dan disepakati bersama.

Penelitian ini masih menyisakan beberapa pertanyaan penting yang dapat dijawab pada penelitian selanjutnya. Beberapa penelitian yang muncul diantaranya adalah (1) Bagaimana membangun komunitas agar dapat mendukung pengembangan kewirausahaan yang optimal, (2) Bagaimana menentukan jenis kewirausahaan yang tepat sesuai dengan karakteristik dari sebuah komunitas, (3) Bagaimana agar pengembangan kewirausahaan dapat berjalan secara selaras dan produktif dengan pengembangan komunitas, (4) Upaya apa yang dapat kita lakukan untuk mendukung pengembangan pelaku wirausaha dalam sebuah komunitas. Tentunya ini menjadi tantangan bagi kami sebagai peneliti kewirausahaan, memperluas ruang lingkup penelitian 
untuk memahami kewirausahaan secara lebih komprehensif dari berbagai sudut pandang.

\section{DAFTAR PUSTAKA}

Aldrich, D. P., \& Meyer, M. A. (2015). Social capital and community resilience. American Behavioral Scientist, 59(2), 254-269.

Anderson, A. R., \& Gaddefors, J. (2016). Entrepreneurship as a community phenomenon; reconnecting meanings and place. International Journal of Entrepreneurship and Small Business, 28(4), 504-518.

Aparicio, S., Urbano, D., \& Audretsch, D. (2016). Institutional factors, opportunity entrepreneurship and economic growth: Panel data evidence. Technological Forecasting and Social Change, 102, 45-61.

Arisena, G. M. K. (2016). Konsep kewirausahaan pada petani melalui pendekatan Structural Equation Model (SEM). Journal of Agribusiness and Agritourism, 44900.

Bridger, J. C., \& Alter, T. R. (2006). Place, community development, and social capital. Community Development, 37(1), 5-18.

Boder, A. (2006). Collective intelligence: A keystone in knowledge management. Journal of Knowledge Management.

Carr, S., \& Roulin, A. (2016). An exploration of Agripreneurship, Scope, Actors and Prospects. Agenda, 2063, 16.

Carree, M. A., \& Thurik, A. R. (2005). Understanding the role of entrepreneurship for economic growth. Papers on Entrepreneurship, Growth and Public Policy.
Chrisman, J. J., Chua, J. H., \& Steier, L. P. (2002). The influence of national culture and family involvement on entrepreneurial perceptions and performance at the state level. Entrepreneurship Theory and Practice, 26(4), 113-130.

Crow, G., \& Allan, G. (2014). Community life. Routledge.

Danes, S. M., Lee, J., Stafford, K., \& Heck, R. K. Z. (2008). The effects of ethnicity, families and culture on entrepreneurial experience: An extension of sustainable family business theory. Journal of Developmental Entrepreneurship, 13(03), 229-268.

Dou, J., Su, E., Li, S., \& Holt, D. T. (2020). Transgenerational entrepreneurship in entrepreneurial families: What is explicitly learned and what is successfully transferred? Entrepreneurship \& Regional Development, 1-15.

Drucker, P. F. (1986). Innovation and entrepreneurship: Practice and principles. Harper \& Row New York.

Edelman, L. F., Brush, C. G., Manolova, T. S., \& Greene, P. G. (2010). Start-up motivations and growth intentions of minority nascent entrepreneurs. Journal of Small Business Management, 48(2), 174196.

Fairlie, R. W. (2013). Entrepreneurship, economic conditions, and the great recession. Journal of Economics \& Management Strategy, 22(2), 207231.

Fortunato, M. W., \& Alter, T. (2015). Community entrepreneurship development: An introduction. Community Development, 46(5), 444-455.

Karlsson, C., Friis, C., \& Paulsson, T. (2004). Relating entrepreneurship to economic growth. The Emerging 
Digital

Economy:

Entrepreneurship Clusters and Policy. Springer-Verlag, Berlin.

Kawachi, I. (1999). Social capital and community effects on population and individual health. Annals of the New York Academy of Sciences, 896(1), 120-130.

Kemmis, D. (2001). Across the great divide: Explorations in collaborative conservation and the American West. Island Press.

Lichtenstein, G. A., \& Lyons, T. S. (2001). The entrepreneurial development system: Transforming business talent and community economies. Economic Development Quarterly, 15(1), 3-20.

Lichtenstein, G. A., \& Lyons, T. S. (2010). Investing in entrepreneurs: A strategic approach for strengthening your regional and community economy. ABC-CLIO.

Lyons, T. S., Alter, T. R., Audretsch, D., \& Augustine, D. (2012). Entrepreneurship and Community: The Next Frontier of Entrepreneurship Inquiry. Entrepreneurship Research Journal, 2(1), 0000102202215756651064. https://doi.org/10.2202/21575665.1064

Martinez, M. A., Yang, T., \& Aldrich, H. E. (2011). Entrepreneurship as an evolutionary process: Research progress and challenges. Entrepreneurship Research Journal, 1(1).
Meredith Geoffrey, G. (2000). Kewirausahaan Teori dan Praktek. Jakarta: PT Pustaka Binaman Pressindo.

Nicotra, M., Romano, M., Del Giudice, M., \& Schillaci, C. E. (2018). The causal relation between entrepreneurial ecosystem and productive entrepreneurship: A measurement framework. The Journal of Technology Transfer, 43(3), 640-673.

Panda, N. M. (2000). What brings entrepreneurial success in a developing region? The Journal of Entrepreneurship, 9(2), 199-212.

Randerson, K., Dossena, G., \& Fayolle, A. (2015). The future of family businesses:

Family entrepreneurship. Futures, in Press.

Sampson, R. J. (2011). The community. Crime and Public Policy, 210-236.

Selsky, J. W., \& Smith, A. E. (1994). Community entrepreneurship: A framework for social change leadership. The Leadership Quarterly, 5(3-4), 277-296.

Shane, S. A. (2003). A general theory of entrepreneurship: The individualopportunity nexus. Edward Elgar Publishing.

Tonnies, F., \& Loomis, C. P. (2002). Community and society. Courier Corporation.

Wellman, B. (1999). The network community: An introduction. Networks in the Global Village, 148.

Zimmerer, T., \& Scarborough, N. M. (1996). Entrepreneurship and new venture formation. Prentice Hall. 